\title{
Data report: stable isotope composition of authigenic carbonates from the northern Cascadia margin, IODP Expedition 311, Sites U1325-U1329'
}

\author{
Catherine Pierre, ${ }^{2}$ Marie-Madeleine Blanc-Valleron, ${ }^{3}$ Jean-Marie Rouchy, ${ }^{3}$ and Danièle Bartier ${ }^{3}$
}

\section{Chapter contents}

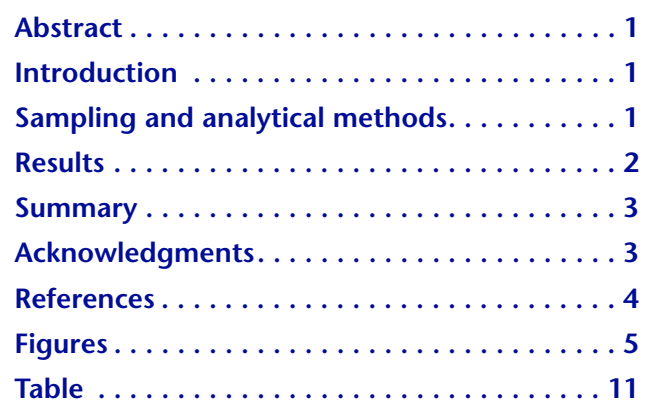

${ }^{1}$ Pierre, C., Blanc-Valleron, M.-M., Rouchy, J.-M., and Bartier, D., 2009. Data report: stable isotope composition of authigenic carbonates from the northern Cascadia margin, IODP Expedition 311, Sites U1325-U1329. In Riedel, M., Collett, T.S., Malone, M.J., and the Expedition 311 Scientists, Proc. IODP, 311: Washington, DC (Integrated Ocean Drilling Program Management International, Inc.). doi:10.2204/iodp.proc.311.210.2009 2 Université Pierre et Marie Curie, LOCEAN, (UMR 7159), 4 place Jussieu, 75252 Paris Cedex 05, France.

catherine.pierre@locean-ipsl.upmc.fr ${ }^{3}$ UMR 5143 CNRS, Département Histoire de la Terre-Géologie, Muséum National d'Histoire Naturelle (MNHN), 43 rue Buffon, 75005 Paris, France.

\section{Abstract}

This report presents the oxygen and carbon stable isotope data obtained on selected authigenic carbonate occurrences from the sediments recovered from five Integrated Ocean Drilling Program sites (U1325-U1329) across the accretionary prism offshore Vancouver Island, where the base of gas hydrate stability zone lies between 124 and 260 meters below seafloor. The two main objectives of this study were to determine if there exists a difference of isotopic compositions between the different sites and to characterize the isotopic signals that might be associated with the presence of gas hydrate at depth.

\section{Introduction}

During Integrated Ocean Drilling Program (IODP) Expedition 311, drilling of four sites (U1325, U1326, U1327, and U1329) along a southwest-northeast transect and of the nearby active vent Site U1328, from 2195 to 946 meters water depth, was realized across the accretionary prism offshore Vancouver Island to study the occurrence of gas hydrate (Fig. F1). Site U1328 corresponds to a cold vent with active fluid and gas flow. At these sites, the bottom seawater temperature varies between $1.8^{\circ} \mathrm{C}$ at the deepest Site U1325 and $3.3^{\circ} \mathrm{C}$ at the shallowest Site U1329 (data obtained from www.ewoce.org); the $\delta^{18} \mathrm{O}$ value of bottom water is probably not far from $-0.17 \%$ standard mean ocean water (SMOW), which is the value of North Pacific Deep Water (Craig and Gordon, 1965).

Stable isotope compositions of a selection of 80 samples of authigenic carbonates were measured to characterize the nature of the diagenetic fluids (i.e., water and carbon sources) from which the carbonates were precipitated.

\section{Sampling and analytical methods}

Sampling of authigenic carbonates was realized onboard the JOIDES Resolution; they occur as light-colored cements, small indurated concretions, or hard rock pieces embedded in the carbonate-poor sediments (Blanc-Valleron et al.). The carbonate content (in weight percent of total sediment) of the 80 selected samples varies between 9 and $89 \mathrm{wt} \%$, with 74 samples containing $>25 \mathrm{wt} \%$ of carbonate. 
The mineralogical composition of samples was systematically determined using X-ray diffraction (XRD) (Blanc-Valleron et al.). The same powder prepared for XRD was used for the isotopic analyses, but it was rinsed with distilled water to eliminate soluble salts that often produce parasite gas during acid attack. Because of the complex mixing of different carbonate minerals in a few samples, it was impossible to separate these phases for isotopic measurements, which thus correspond to the composition of bulk carbonate.

The oxygen and carbon isotope compositions of carbonates are expressed in the conventional $\delta$ notation defined as

$$
\delta=[(\operatorname{Rs} / \operatorname{Rr})-1] \times 1000,
$$

where $\mathrm{R}={ }^{18} \mathrm{O} /{ }^{16} \mathrm{O}$ or ${ }^{13} \mathrm{C} /{ }^{12} \mathrm{C}$, respectively, in the sample (Rs) and in the reference (Rr). The reference for $\delta^{18} \mathrm{O}$ and $\delta^{13} \mathrm{C}$ is Vienna Peedee belemnite (VPDB) (Craig, 1957). The $\mathrm{CO}_{2}$ gas extracted from the carbonate by digestion with $100 \%$ phosphoric acid at $25^{\circ} \mathrm{C}(24 \mathrm{~h}$ for calcium carbonate and $72 \mathrm{~h}$ to 1 week for dolomite, siderite, and rhodochrosite and composite mixtures of various carbonate phases) was analyzed with a triple collector mass spectrometer (VG Sira 9). The analytical precision was $0.01 \%$ for both $\delta^{18} \mathrm{O}$ and $\delta^{13} \mathrm{C}$; the reproducibility was generally better than $0.1 \%$ for $\delta^{18} \mathrm{O}$ and $\delta^{13} \mathrm{C}$.

The oxygen isotopic compositions of calcite and dolomite precipitated in isotopic equilibrium with the bottom seawater may be evaluated using the equations of O'Neil et al. (1969) and Fritz and Smith (1970), respectively. These calculated theoretical $\delta^{18} \mathrm{O}$ values vary between $2.96 \%$ and $3.35 \%$ or calcite and between $5.97 \%$ and $6.35 \%$ for dolomite and may thus be compared to the $\delta^{18} \mathrm{O}$ values measured in the authigenic carbonates.

\section{Results}

The carbonate mineralogy is generally very complex, with mixtures of calcium carbonates (calcite and aragonite), dolomite, and occasionally rhodochrosite and siderite. There are no obvious carbonate mineralogical variations with depth, especially in relation to the location of the base of the gas hydrate stability zone (BGHSZ) (Blanc-Valleron et al.). However, it is important to notice that siderite and rhodochrosite occurrences are limited to sedimentary layers lower than 125 meters below seafloor (mbsf).

The analytical results for authigenic carbonates are reported in Table T1 with both carbonate mineralogy and oxygen and carbon isotopic compositions.

\section{Oxygen and carbon isotopic compositions of carbonates from all sites}

Oxygen and carbon isotope compositions display large ranges of variations (Fig. F2). The widest ranges are measured in calcite/aragonite: $-1.27 \% 0<\delta^{18} \mathrm{O}<$ $6.58 \%$ and $-51.61 \% 0<\delta^{13} \mathrm{C}<23.38 \%$. There is one sample (311-U1329C-22X-CC, $72-74 \mathrm{~cm})$ that falls far off this range with a $\delta^{18} \mathrm{O}$ value of $-8.68 \%$; its microsparitic facies does not correspond to that of an authigenic carbonate (Blanc-Valleron et al.), and it was thus excluded from the plots. Dolomite also exhibits large variations: $3.31 \% 0<\delta^{18} \mathrm{O}<7.73 \%$ and $38.35 \%$ o $<\delta^{13} \mathrm{C}<33.46 \%$. Carbonate mixtures appear very similar to dolomite: $2.10 \% 0<\delta^{18} \mathrm{O}<$ $6.79 \%$ and $-41.49 \% 0<\delta^{13} \mathrm{C}<37.55 \%$.

The $\delta^{18} \mathrm{O}$ values of dolomite, as well as of carbonate mixtures, are generally shifted by a few permil compared to the calcite/aragonite values, as it is expected that dolomite, siderite, and rhodochrosite are enriched in ${ }^{18} \mathrm{O}$ relative to calcite precipitated in similar conditions. There is also a significant difference in the $\delta^{13} \mathrm{C}$ values of the carbonate phases that are $\sim 10 \%$ o lower in calcite/aragonite compared to dolomite and most of the carbonate mixtures.

These values are very similar to those measured on authigenic carbonates sampled during previous cruises on the Cascadia margin (Ocean Drilling Program [ODP] Legs 146 and 204) and Hydrate Ridge (SO109 and SO110 cruises of GEOMAR) (Kastner et al., 1995a, 1995b; Kopf et al., 1995; Sample and Kopf, 1995; Greinert et al., 2001).

\section{Oxygen and carbon isotopic distributions with depth}

\section{Site U1325}

Site U1325, drilled to $2195 \mathrm{mbsf}$, is located within the first slope basin in the southwestern part of the transect. The BGHSZ depth was estimated at 240.5 mbsf. Based on pore water chemistry, the presence of gas hydrates has been inferred in the sandy layers from 70 to 240 mbsf (see the "Site U1325" chapter; Torres et al., 2008).

Two samples were taken above and one sample was taken below the BGHSZ (Table T1). These three samples exhibit very similar $\delta^{18} \mathrm{O}$ values, but their $\delta^{13} \mathrm{C}$ values decrease abruptly from $-3.94 \%$ at 221.98 mbsf to $-30.23 \%$ at 258.29 mbsf, below the BGHSZ.

\section{Site U1326}

Site U1326, drilled to 1828 mbsf, is located on top of the first uplifted ridge of accreted sediments at the far western downslope end of the transect. The 
BGHSZ depth was estimated at 260 mbsf. Pore water analysis indicated that gas hydrates were disseminated in the sandy layers below $40 \mathrm{mbsf}$ (see the "Site U1326" chapter; Torres et al., 2008).

There are important variations of $\delta^{18} \mathrm{O}$ and $\delta^{13} \mathrm{C}$ values with depth at this site (Fig. F3A, F3B). The diagenetic carbonates are characterized by high $\delta^{18} \mathrm{O}$ values and low $\delta^{13} \mathrm{C}$ values to $118.75 \mathrm{mbsf}$, and they exhibit low $\delta^{18} \mathrm{O}$ values and slightly positive $\delta^{13} \mathrm{C}$ values from 155.9 to $263.75 \mathrm{mbsf}$. The sample located at 235.9 mbsf has the lowest $\delta^{18} \mathrm{O}$ value $(-1.27 \%$ ) measured at this site.

\section{Site U1327}

Site U1327, drilled to $1304 \mathrm{mbsf}$, is located on the midcontinental slope off Vancouver Island, several hundred meters from Site 889 (ODP Leg 146). The BGHSZ depth was estimated at 230 mbsf. Gas hydrates were found above the BGHSZ to 128 mbsf (see the "Site U1327" chapter; Torres et al., 2008).

The $\delta^{18} \mathrm{O}$ and $\delta^{13} \mathrm{C}$ values are randomly distributed with depth, being alternatively low and high between 126.4 and 178.43 mbsf (Fig. F4A, F4B). The two samples of authigenic carbonates at $228 \mathrm{mbsf}$ (i.e., very close to the BGHSZ) have similar relatively low $\delta^{18} \mathrm{O}$ values $\left(0.45 \%\right.$ and $0.53 \%$ ) and high $\delta^{13} \mathrm{C}$ values $(23.33 \%$ and $23.38 \%$ ).

\section{Site U1328}

Site U1328, drilled to $1268 \mathrm{mbsf}$, is located $3.7 \mathrm{~km}$ southeast of Site U1327 on the midcontinental slope off Vancouver Island. The BGHSZ depth was estimated at 219 mbsf (see the "Site U1328" chapter). Gas hydrates were present in two main layers: at the subsurface (0-35 mbsf) and just above the BGHSZ (215-222 mbsf).

$\delta^{18} \mathrm{O}$ values show a rapid decrease by $\sim 3 \%$ from the uppermost levels down to 36.46 mbsf followed by an increase by $\sim 2.5 \%$ just at the BGHSZ depth; below the BGHSZ, $\delta^{18} \mathrm{O}$ values fluctuate between $4.66 \%$ o and $7.42 \%$ in authigenic dolomite (Fig. F5A). There is a strong difference in $\delta^{13} \mathrm{C}$ values of the authigenic carbonates that are very low above the BGHSZ (as low as $-51.61 \%$ ) and increase abruptly by $53 \%$ below the BGHSZ to reach values of $11.3 \%$ (Fig. F5B).

\section{Site U1329}

Site U1329 was the easternmost and shallowest site (946 mbsf) of the transect. The BGHSZ depth is much shallower than at the other sites and was estimated at 124 mbsf (see the "Site U1329" chapter). At this site, only minor amounts of gas hydrates are supposed to occur above the BGHSZ, but there is no significant chloride anomaly in pore water.

$\delta^{18} \mathrm{O}$ values are more dispersed in calcite and carbonate mixtures than in dolomite (Fig. F6A, F6B). $\delta^{18} \mathrm{O}$ values of dolomite show an obvious depth variation from high values $(7.07 \%$ at $31.13 \mathrm{mbsf}$ to $6.93 \%$ at 104.35 mbsf) above the BGHSZ to progressively decreasing values below the BGHSZ with the lowermost value of $4.30 \%$ at 176.3 mbsf. There is also a significant change in $\delta^{13} \mathrm{C}$ values of dolomite with depth, with negative values $(-22.55 \%$ o to $-6.39 \%$ ) above the BGHSZ and highly positive values (21.18\% to $33.46 \%$ ) below the BGHSZ. It is at Site U1329 that the highest $\delta^{13} \mathrm{C}$ values have been measured in the authigenic dolomite and in a sideriterich carbonate mixture $\left(\delta^{13} \mathrm{C}=37.55 \%\right)$ at 150.5 mbsf. Such high $\delta^{13} \mathrm{C}$ values have been reported in very rare authigenic carbonate occurrences as in $\mathrm{Hy}$ drate Ridge (Greinert et al., 2001).

\section{Summary}

This data report presents new stable isotope results of authigenic carbonates from the Cascadia margin, IODP Expedition 311. There is a general trend both for calcite and dolomite of decreasing $\delta^{18} \mathrm{O}$ values and increasing $\delta^{13} \mathrm{C}$ values with depth. At Sites $\mathrm{U} 1328$ and $\mathrm{U} 1329$, there is a sharp gradient of $\delta^{13} \mathrm{C}$ values of dolomite crossing the BGHSZ that corresponds to the transition from negative $\delta^{13} \mathrm{C}$ values above the BGHSZ to positive $\delta^{13} \mathrm{C}$ values below the BGHSZ; a similar $\delta^{13} \mathrm{C}$ gradient is evidenced at Site U1327 for calcite. However, this transition occurs $\sim 110 \mathrm{~m}$ above the BGHSZ at Site U1326 and it is absent at Site U1325.

The strong lateral heterogeneity between adjacent boreholes noticed in the preliminary conclusions of Expedition 311 is therefore also evidenced in the distribution of the stable isotope compositions of authigenic carbonates.

\section{Acknowledgments}

The authors would like to thank Marie José Urrutiaguer for stable isotope analyses. This research used samples and/or data provided by the Integrated Ocean Drilling Program (IODP). Funding for this research was provided by an Eclipse II grant of the CNRS.

The manuscript benefited from helpful comments by Mitchell Malone and Professor Ryo Matsumoto, who are warmly acknowledged for their collaboration. 


\section{References}

Craig, H., 1957. Isotopic standards for carbon and oxygen and correction factors for mass-spectrometric analysis of carbon dioxide. Geochim. Cosmochim. Acta, 12(12):133-149. doi:10.1016/0016-7037(57)90024-8

Craig, H., and Gordon, L.I., 1965. Deuterium and oxygen 18 variations in the ocean and the marine atmosphere. In Tongiorgi, E. (Ed.), Stable Isotopes in Oceanographic Studies and Paleotemperatures: Pisa, Italy (Consiglio Nazionale delle Ricerche Laboratorio di Geologia Nucleare), 9-130.

Fritz, P., and Smith, D.G.W., 1970. The isotopic composition of secondary dolomites. Geochim. Cosmochim. Acta., 34(11):1161-1173. doi:10.1016/00167037(70)90056-6

Greinert, J., Bohrmann, G., and Suess, E., 2001. Gas hydrate-associated carbonates and methane-venting at Hydrate Ridge: classification, distribution and origin of authigenic lithologies. In Paul, C.K., and Dillon, W.P. (Eds.), Natural Gas Hydrates: Occurrence, Distribution, and Detection. Geophys. Monogr., 124:99-113.

Kastner, M., Kvenvolden, K.A., Whiticar, M.J., Camerlenghi, A., and Lorenson, T.D., 1995. Relation between pore fluid chemistry and gas hydrates associated with bottom-simulating reflectors at the Cascadia margin, Sites 889 and 892. In Carson, B., Westbrook, G.K., Musgrave, R.J., and Suess, E. (Eds.), Proc. ODP, Sci. Results, 146 (Pt. 1): College Station, TX (Ocean Drilling Program), 175-187. doi:10.2973/odp.proc.sr.1461.213.1995

Kastner, M., Sample, J.C., Whiticar, M.J., Hovland, M., Cragg, B.A., and Parkes, J.R., 1995. Geochemical evidence for fluid flow and diagenesis at the Cascadia convergent margin. In Carson, B., Westbrook, G.K.,
Musgrave, R.J., and Suess, E. (Eds.), Proc. ODP, Sci. Results, 146 (Pt. 1): College Station, TX (Ocean Drilling Program), 375-384. doi:10.2973/odp.proc.sr.1461.243.1995

Kopf, A., Sample, J.C., Bauer, P., Behrmann, J.H., and Erlenkeuser, H., 1995. Diagenetic carbonates from Cascadia margin: textures, chemical compositions, and oxygen and carbon stable isotope signatures. In Carson, B., Westbrook, G.K., Musgrave, R.J., and Suess, E. (Eds.), Proc. ODP, Sci. Results, 146 (Pt. 1): College Station, TX (Ocean Drilling Program), 117-136. doi:10.2973/ odp.proc.sr.146-1.234.1995

O'Neil, J.R., Clayton, R.N., and Mayeda, T.K., 1969. Oxygen isotope fractionation in divalent metal carbonates. J. Chem. Phys., 51:5547-5558.

Sample, J.C., and Kopf, A., 1995. Isotope geochemistry of syntectonic carbonate cements and veins from the Oregon margin: implications for the hydrogeologic evolution of the accretionary wedge. In Carson, B., Westbrook, G.K., Musgrave, R.J., and Suess, E. (Eds.), Proc. ODP, Sci. Results, 146 (Pt. 1): College Station, TX (Ocean Drilling Program), 137-148. doi:10.2973/ odp.proc.sr.146-1.235.1995

Torres, M.E., Tréhu, A.M., Cespedes, N., Kastner, M., Wortmann, U.G., Kim, J.-H., Long, P., Malinverno, A., Pohlman, J.W., Riedel, M., and Collett, T., 2008. Methane hydrate formation in turbidite sediments of northern Cascadia, IODP Expedition 311. Earth Planet. Sci. Lett., 271(1-4):170-180. doi:10.1016/j.epsl.2008.03.061

Initial receipt: 26 June 2008

Acceptance: 4 December 2008

Publication: 5 May 2009

MS 311-210 
Figure F1. A. Map of plate tectonic setting of the Cascadia margin with general location of the drilling transect near previous ODP Sites 889/890. Bottom-simulating reflector is present on $\sim 50 \%$ of the midcontinental slope (shaded area) (from Riedel et al., 2006). B. Multibeam bathymetry map along the transect across the accretionary prism, showing the location of the drilling transect (Sites U1326, U1325, U1327, U1329), cold vent Site U1328, and multichannel seismic (MCS) Line 89-08 (Courtesy of D. Kelley, J. Delaney, and D. Glickson, University of Washington and C. Barnes and C. Katnick, Neptune Canada, University of Victoria; funded by the University of Washington and the W.M. Keck Foundation).

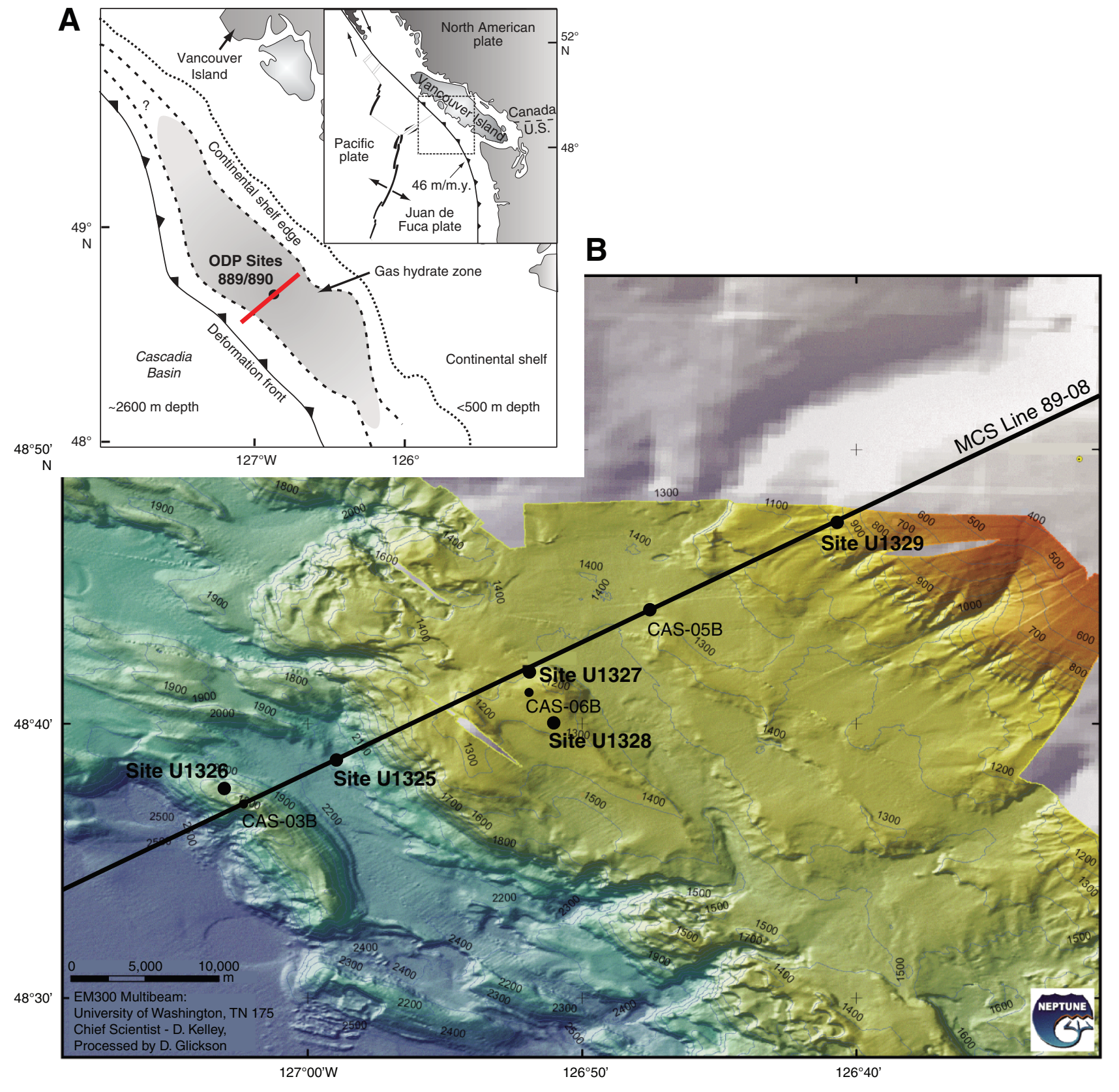


Figure F2. Plot of oxygen and carbon isotopic compositions of authigenic carbonates, Sites U1325, U1326, U1327, U1328, and U1329. Open circle = calcite/aragonite, solid circle = dolomite, open square = carbonate mixture. VPDB = Vienna Peedee belemnite.

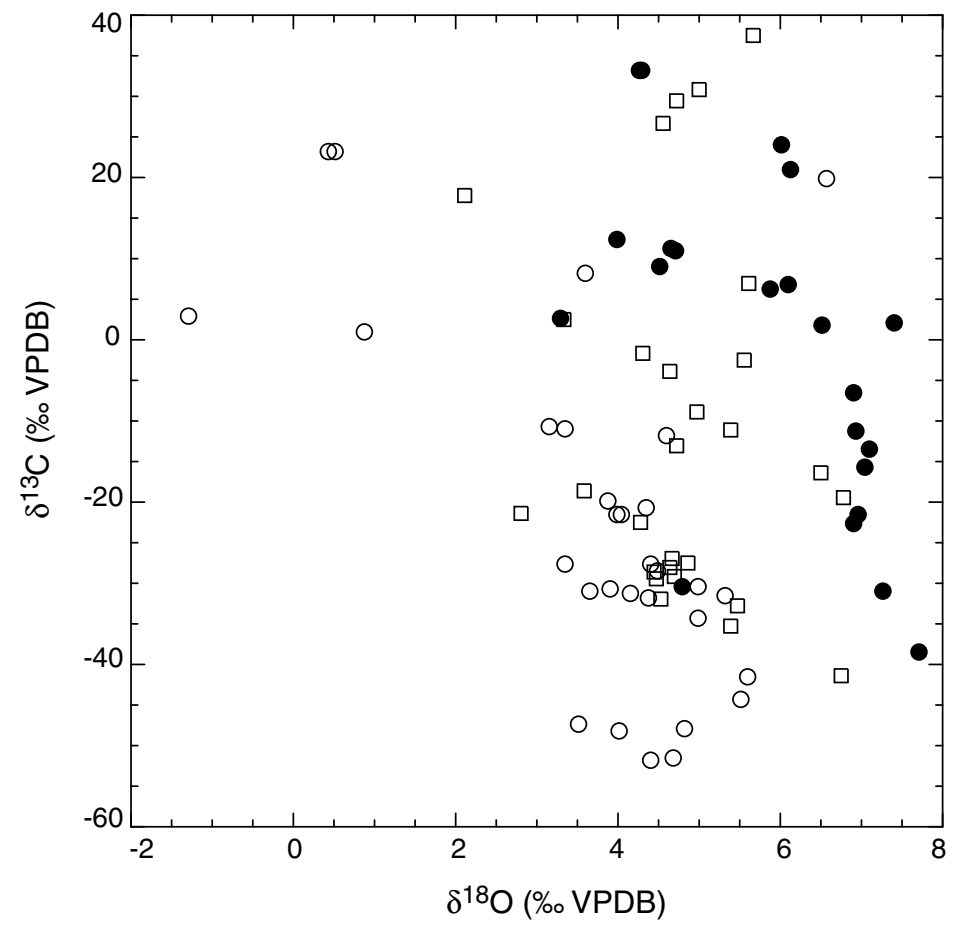


Figure F3. Plots of variations with depth of $(\mathbf{A}) \delta^{18} \mathrm{O}$ and $(\mathbf{B}) \delta^{13} \mathrm{C}$ values of diagenetic carbonates, Site U1326. Open circle $=$ calcite $/$ aragonite, solid circle $=$ dolomite, open square $=$ carbonate mixture VPDB $=$ Vienna Peedee belemnite. BGHSZ = base of the gas hydrate stability zone.
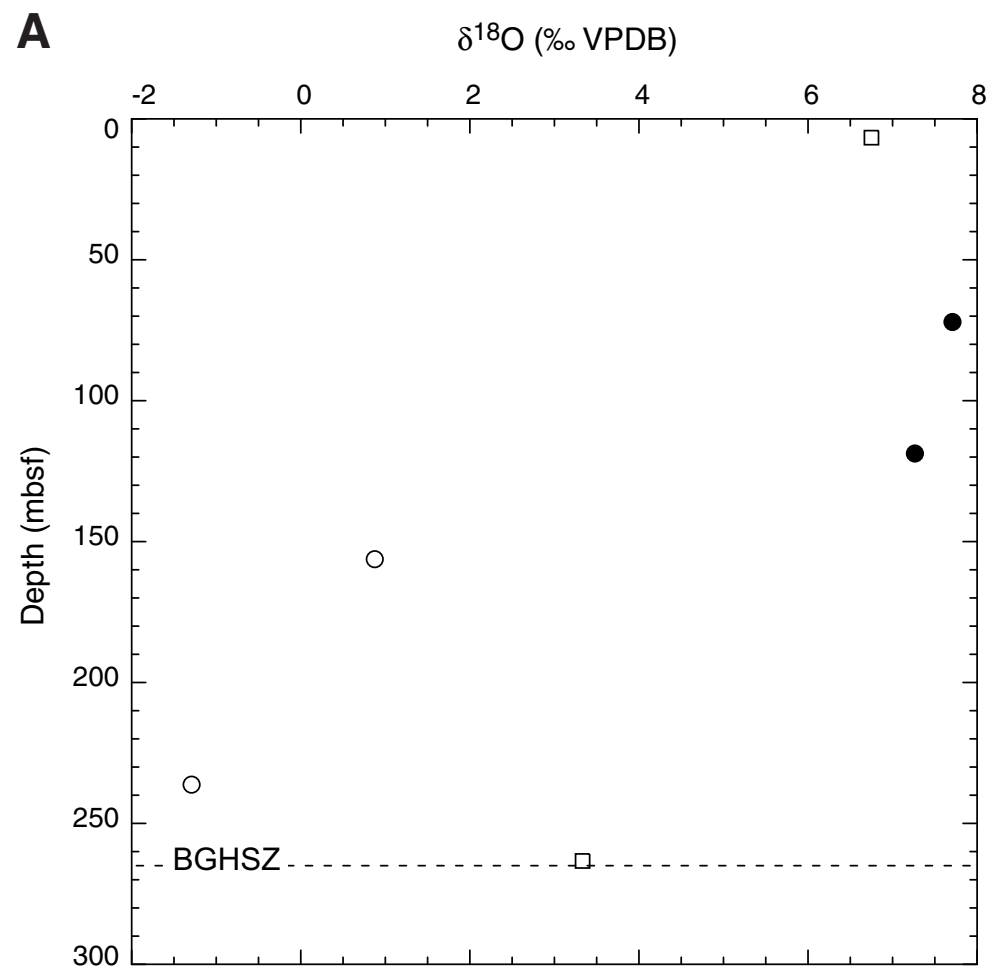

B

$\delta^{13} \mathrm{C}(\% \circ \mathrm{VPDB})$

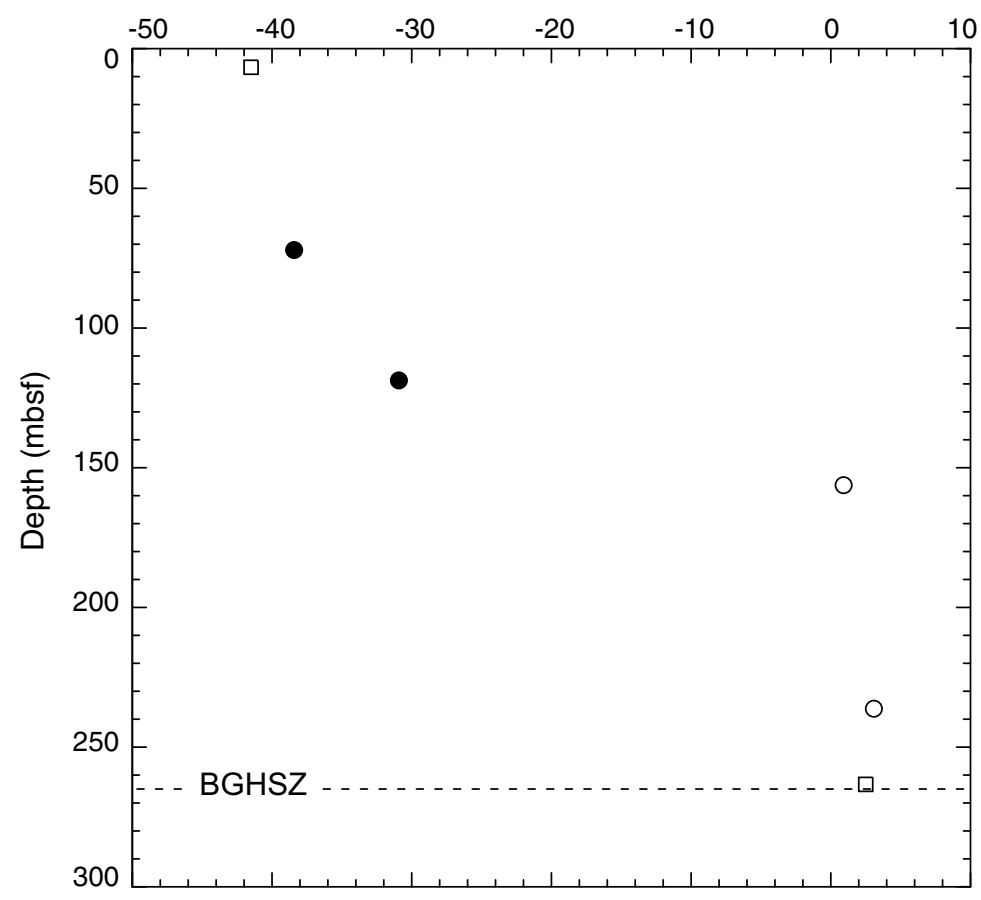


Figure F4. Plots of variations with depth of (A) $\delta^{18} \mathrm{O}$ and $(\mathbf{B}) \delta^{13} \mathrm{C}$ values of diagenetic carbonates, Site U1327. Open circle $=$ calcite/aragonite, solid circle $=$ dolomite, open square $=$ carbonate mixture. VPDB $=$ Vienna Peedee belemnite. BGHSZ = base of the gas hydrate stability zone.
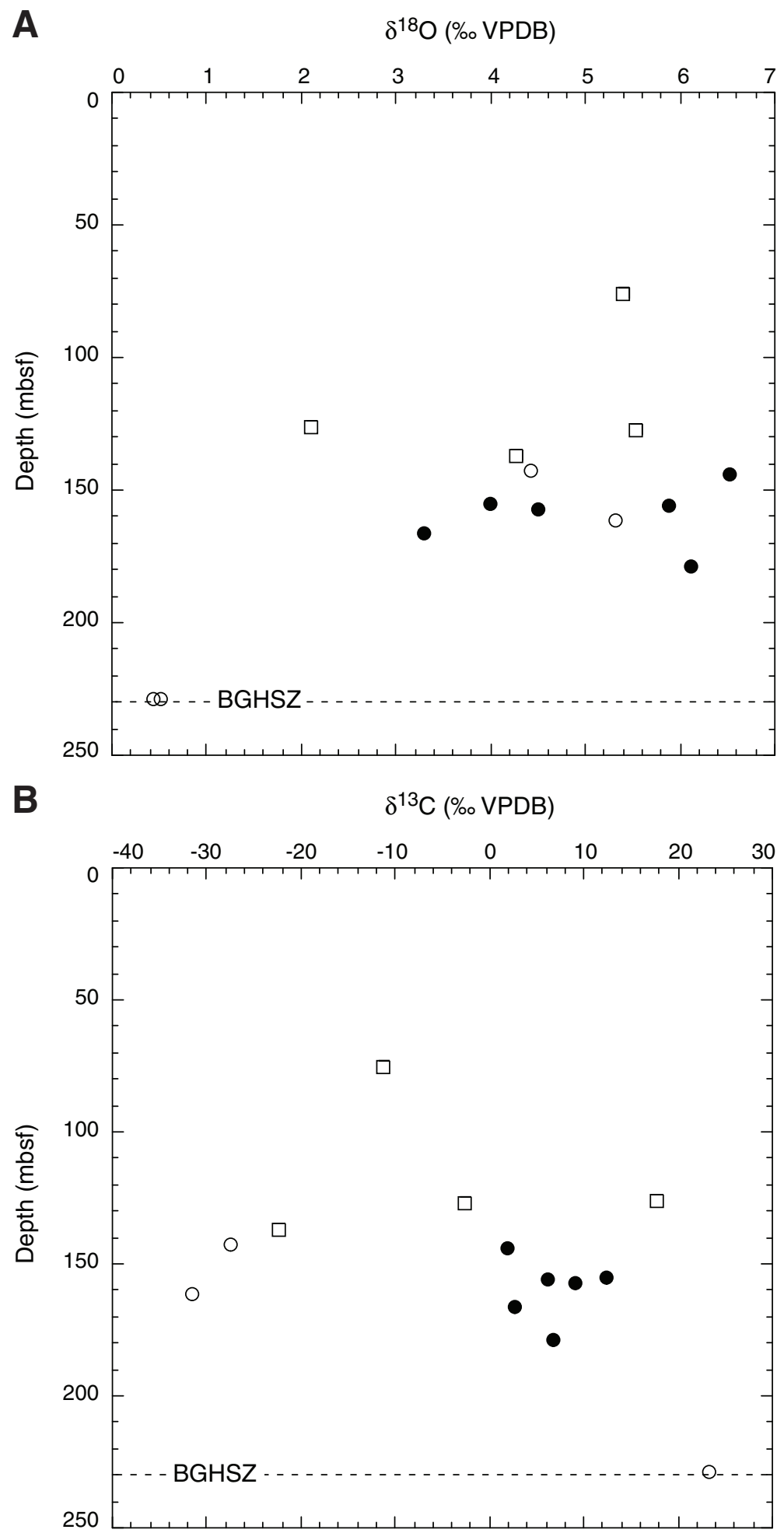
Figure F5. Plots of variations with depth of $(\mathbf{A}) \delta^{18} \mathrm{O}$ and $(\mathbf{B}) \delta^{13} \mathrm{C}$ values of diagenetic carbonates, Site U1328. Open circle $=$ calcite $/$ aragonite, solid circle $=$ dolomite, open square $=$ carbonate mixture VPDB $=$ Vienna Peedee belemnite. BGHSZ = base of the gas hydrate stability zone.
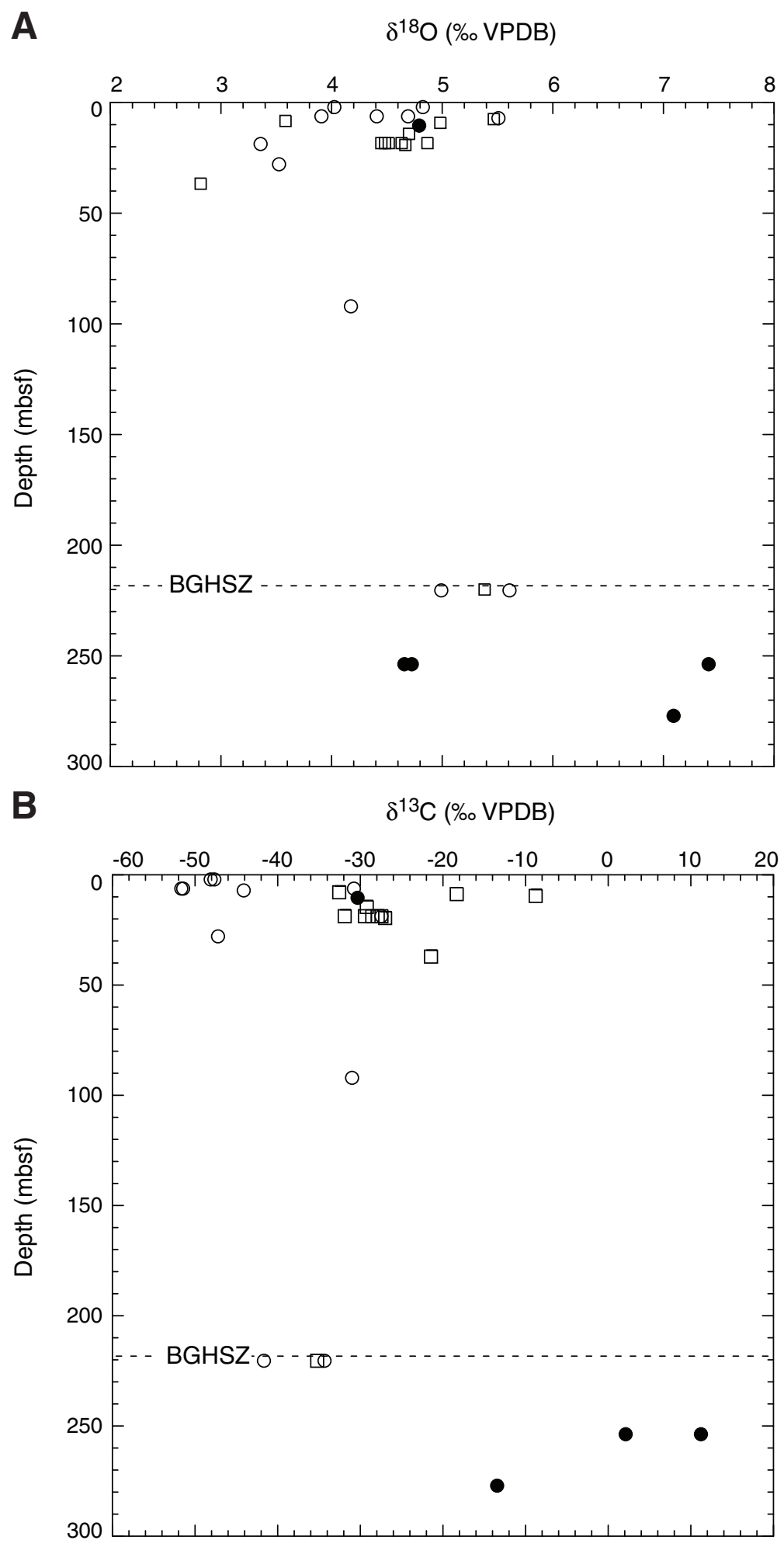
Figure F6. Plots of variations with depth of $(A) \delta^{18} \mathrm{O}$ and $(\mathbf{B}) \delta^{13} \mathrm{C}$ values of diagenetic carbonates, Site U1329. Open circle $=$ calcite/aragonite, solid circle $=$ dolomite, open square $=$ carbonate mixture VPDB $=$ Vienna Peedee belemnite. BGHSZ = base of the gas hydrate stability zone.

A

$\delta^{18} \mathrm{O}(\% \circ \mathrm{VPDB})$

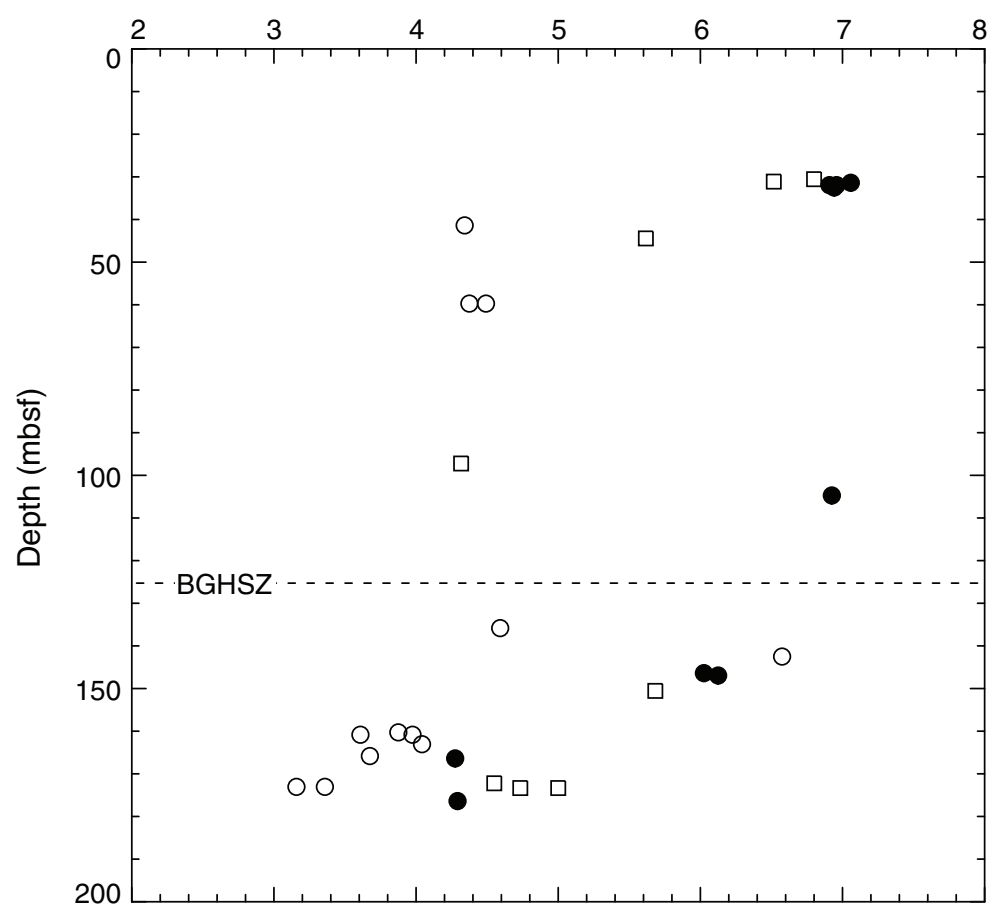

B

$\delta^{13} \mathrm{C}(\% \circ \mathrm{VPDB})$

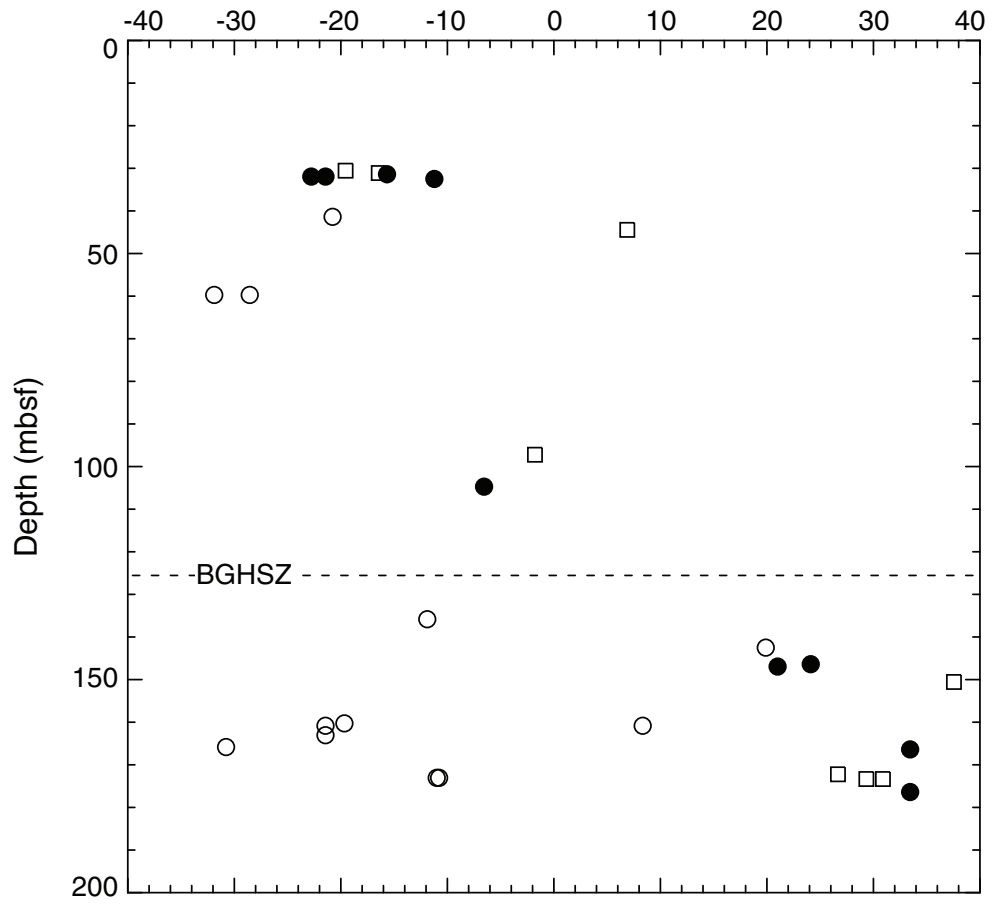


Table T1. Total carbonate content, mineralogy, and oxygen and carbon isotopic compositions of the carbonate fraction of diagenetic carbonate concretions, Sites U1325, U1326, U1327, U1328 and U1329. (See table notes.) (Continued on next page.)

\begin{tabular}{|c|c|c|c|c|c|c|c|c|c|c|c|c|}
\hline \multirow{2}{*}{$\begin{array}{l}\text { Core, section, } \\
\text { interval }(\mathrm{cm})\end{array}$} & \multirow{2}{*}{$\begin{array}{l}\text { Depth } \\
\text { (mbsf) }\end{array}$} & \multirow{2}{*}{$\begin{array}{c}\text { Total } \\
\text { carbonate } \\
\text { (wt\%) }\end{array}$} & \multirow{2}{*}{$\begin{array}{c}\text { Aragonite } \\
\text { (relative \%) }\end{array}$} & \multirow{2}{*}{$\begin{array}{c}\text { Calcite } \\
\text { (relative \%) }\end{array}$} & \multirow{2}{*}{$\begin{array}{c}\text { Dolomite } \\
\text { (relative \%) }\end{array}$} & \multirow{2}{*}{$\begin{array}{l}\text { Other carbonate } \\
\text { (relative \%) }\end{array}$} & \multicolumn{2}{|c|}{$\begin{array}{c}\text { Calcite/Aragonite } \\
\text { (\%o VPDB) }\end{array}$} & \multicolumn{2}{|c|}{$\begin{array}{l}\text { Dolomite } \\
\text { (\%o VPDB) }\end{array}$} & \multicolumn{2}{|c|}{$\begin{array}{c}\text { Carbonate mixture } \\
\text { (\%o VPDB) }\end{array}$} \\
\hline & & & & & & & $\delta^{18} \mathrm{O}$ & $\delta^{13} \mathrm{C}$ & $\delta^{18} \mathrm{O}$ & $\delta^{13} \mathrm{C}$ & $\delta^{18} \mathrm{O}$ & $\delta^{13} \mathrm{C}$ \\
\hline \multicolumn{13}{|l|}{$311-$} \\
\hline U1325B-16X-6, 28 & 126.93 & 29 & & 41 & 59 & & & & & & 4.71 & -13.14 \\
\hline U1325C-6X-4, 47 & 221.98 & 65 & & 8 & 92 & & & & & & 4.65 & -3.94 \\
\hline U1325C-11X-1, 119 & 258.29 & 69 & & 93 & 7 & & 5.01 & -30.23 & & & & \\
\hline U1326C-2H-2, 92 & 6.32 & 64 & & 23 & 77 & & & & & & 6.74 & -41.49 \\
\hline U1326C-9X-2, 92 & 71.52 & 80 & & 1 & 99 & & & & 7.73 & -38.35 & & \\
\hline U1326D-5X-2, 5 & 118.75 & 67 & & 4 & 96 & & & & 7.28 & -30.87 & & \\
\hline U1326D-9X-1, 0 & 155.90 & 16 & & 100 & & & 0.88 & 1.05 & & & & \\
\hline U1326D-17X-3, 0 & 235.90 & 16 & & 100 & & & -1.27 & 3.15 & & & & \\
\hline U1326D-20X-3, 0 & 263.75 & 33 & & 33 & 7 & $59^{*}$ & & & & & 3.34 & 2.5 \\
\hline U1327C-10H-1, 96 & 75.56 & 24 & & 73 & 27 & & & & & & 5.4 & -11.23 \\
\hline U1327C-16X-2, 120 & 126.40 & 11 & & 22 & 6 & 72 & & & & & 2.10 & 17.78 \\
\hline U1327D-5X-1, 65 & 126.95 & 64 & & 48 & 52 & & & & & & 5.55 & -2.57 \\
\hline U1327C-17X-CC, 13 & 136.77 & 67 & & 83 & 17 & & & & & & 4.28 & -22.37 \\
\hline U1327C-18X-2, 0 & 142.35 & 67 & & 88 & 12 & & 4.43 & -27.44 & & & & \\
\hline U1327C-18X-2, 130 & 143.65 & 76 & & 3 & 97 & & & & 6.54 & 2.04 & & \\
\hline U1327D-10P-1, 0 & 155.10 & 85 & & 4 & 96 & & & & 3.99 & 12.53 & & \\
\hline U1327D-10P-1, 78 & 155.88 & 64 & & 31 & 69 & & & & 5.89 & 6.27 & & \\
\hline U1327D-11X-1, 0 & 157.10 & 67 & & 6 & 94 & & & & 4.52 & 9.13 & & \\
\hline U1327C-20X-1, 0 & 160.80 & 49 & & 98 & 2 & & 5.33 & -31.46 & & & & \\
\hline U1327C-20X-5, 6 & 166.14 & 9 & & 75 & 17 & 7 & & & 3.31 & 2.77 & & \\
\hline U1327C-21X-7, 0 & 178.43 & 82 & & 1 & 99 & & & & 6.12 & 6.93 & & \\
\hline U1327D-16X-CC, 10 & 228.40 & 62 & & 98 & 2 & & 0.45 & 23.33 & & & & \\
\hline U1327D-16X-CC, 18 & 228.48 & 68 & & 94 & 6 & & 0.53 & 23.38 & & & & \\
\hline U1328B-1H-2, 8 & 1.58 & 30 & & 82 & 18 & & 4.83 & -47.65 & & & & \\
\hline U1328D-1X-2, 40 & 1.90 & 31 & & 91 & 9 & & 4.04 & -48.02 & & & & \\
\hline U1328D-1X-5, 9 & 6.09 & 43 & & 97 & 3 & & 4.42 & -51.61 & & & & \\
\hline U1328D-1X-5, 10 & 6.10 & 50 & & 97 & 3 & & 4.7 & -51.25 & & & & \\
\hline U1328B-3X-CC, 0 & 6.20 & 77 & 30 & 68 & 2 & & 3.92 & -30.62 & & & & \\
\hline U1328E-2X-1, 52 & 7.02 & 70 & & 100 & & & 5.52 & -44.06 & & & & \\
\hline U1328D-1X-5, 135 & 7.35 & 84 & & 81 & 19 & & & & & & 5.47 & -32.74 \\
\hline U1328D-1X-CC, 0 & 8.10 & 40 & & 27 & 73 & & & & & & 3.59 & -18.52 \\
\hline U1328D-2X-2, 30 & 9.43 & 68 & & 30 & 70 & & & & & & 4.98 & -8.78 \\
\hline U1328D-2X-CC, 0 & 10.02 & 61 & & 8 & 92 & & & & 4.8 & -30.15 & & \\
\hline U1328B-4P-1, 0 & 14.50 & 70 & 13 & 72 & 16 & & & & & & 4.7 & -29.26 \\
\hline U1328B-6X-1, 0 (A) & 18.40 & 71 & 8 & 82 & 10 & & & & & & 4.52 & -31.95 \\
\hline U1328B-6X-1, 0 (B) & 18.40 & 72 & 8 & 77 & 14 & & & & & & 4.48 & -29.52 \\
\hline U1328B-6X-1, 25 & 18.65 & 70 & & 87 & 13 & & & & & & 4.45 & -28.59 \\
\hline U1328B-6X-1, 30 & 18.70 & 60 & & 88 & 12 & & & & & & 4.87 & -27.47 \\
\hline U1328B-6X-1, 35 & 18.75 & 41 & & 96 & 4 & & 3.36 & -27.38 & & & & \\
\hline U1328B-6X-1, 36 & 18.76 & 69 & 11 & 62 & 27 & & & & & & 4.64 & -28.05 \\
\hline U1328B-6X-1, 47 & 18.87 & 71 & & 87 & 13 & & & & & & 4.67 & -27.01 \\
\hline U1328E-8X-1, 97 & 27.67 & 67 & & 96 & 4 & & 3.53 & -47.21 & & & & \\
\hline U1328E-9X-1, 16 & 36.46 & 68 & & 85 & 15 & & & & & & 2.82 & -21.51 \\
\hline U1328C-5P-1, 0 & 92.00 & 84 & 46 & 48 & 5 & & 4.18 & -30.96 & & & & \\
\hline U1328C-19X-4, 24 & 220.27 & 14 & & 94 & 6 & & 4.99 & -34.22 & & & & \\
\hline U1328C-19X-4, 26 & 220.29 & 50 & & 80 & 20 & & & & & & 5.38 & -35.24 \\
\hline U1328C-19X-4, 32 & 220.35 & 58 & & 92 & 8 & & 5.62 & -41.47 & & & & \\
\hline
\end{tabular}




\begin{tabular}{|c|c|c|c|c|c|c|c|c|c|c|c|c|}
\hline \multirow{2}{*}{$\begin{array}{l}\text { Core, section, } \\
\text { interval }(\mathrm{cm})\end{array}$} & \multirow{2}{*}{$\begin{array}{l}\text { Depth } \\
\text { (mbsf) }\end{array}$} & \multirow{2}{*}{$\begin{array}{c}\text { Total } \\
\text { carbonate } \\
(w t \%)\end{array}$} & \multirow{2}{*}{$\begin{array}{c}\text { Aragonite } \\
\text { (relative \%) }\end{array}$} & \multirow{2}{*}{$\begin{array}{c}\text { Calcite } \\
\text { (relative \%) }\end{array}$} & \multirow{2}{*}{$\begin{array}{c}\text { Dolomite } \\
\text { (relative \%) }\end{array}$} & \multirow{2}{*}{$\begin{array}{l}\text { Other carbonate } \\
\text { (relative \%) }\end{array}$} & \multicolumn{2}{|c|}{$\begin{array}{c}\text { Calcite/Aragonite } \\
\text { (\%o VPDB) }\end{array}$} & \multicolumn{2}{|c|}{$\begin{array}{l}\text { Dolomite } \\
\text { (\%o VPDB) }\end{array}$} & \multicolumn{2}{|c|}{$\begin{array}{c}\text { Carbonate mixture } \\
\text { (\%० VPDB) }\end{array}$} \\
\hline & & & & & & & $\delta^{18} \mathrm{O}$ & $\delta^{13} \mathrm{C}$ & $\delta^{18} \mathrm{O}$ & $\delta^{13} \mathrm{C}$ & $\delta^{18} \mathrm{O}$ & $\delta^{13} \mathrm{C}$ \\
\hline U1328C-22X-CC, 12 & 253.70 & 79 & & & 100 & & & & 7.42 & 2.13 & & \\
\hline U1328C-22X-CC, 20-21 & 253.78 & 36 & & 13 & 87 & & & & 4.66 & 11.3 & & \\
\hline U1328C-22X-CC, 20-22 & 253.78 & 71 & & 2 & 98 & & & & 4.73 & 11.25 & & \\
\hline U1328C-25X-2, 77 & 276.37 & 59 & & 3 & 97 & & & & 7.1 & -13.4 & & \\
\hline U1329E-4H-5, 48 & 30.48 & 68 & & 11 & 89 & & & & & & 6.79 & -19.51 \\
\hline U1329E-4H-5, 93 & 30.93 & 36 & & 10 & 90 & & & & & & 6.5 & -16.47 \\
\hline U1329E-4H-5, 113 & 31.13 & 70 & & 1 & 99 & & & & 7.07 & -15.63 & & \\
\hline U1329C-4H-3, 138 & 31.48 & 35 & & & 100 & & & & 6.92 & -22.55 & & \\
\hline U1329C-4H-3, 140 & 31.50 & 59 & & & 100 & & & & 6.97 & -21.3 & & \\
\hline U1329E-4H-6,72-74 & 32.22 & 43 & & 5 & 95 & & & & 6.95 & -11.17 & & \\
\hline U1329C-5H-3, 129 & 40.89 & 15 & & 100 & & & 4.35 & -20.63 & & & & \\
\hline U1329C-5H-6, 61 & 44.71 & 26 & & 30 & 70 & & & & & & 5.6 & 6.82 \\
\hline U1329C-8H-2, 58 & 59.68 & 80 & & 100 & & & 4.39 & -31.67 & & & & \\
\hline U1329C-8H-2, 62 & 59.72 & 54 & & 100 & & & 4.5 & -28.34 & & & & \\
\hline U1329C-12H-2, 36 & 97.44 & 28 & & 67 & 33 & & & & & & 4.3 & -1.66 \\
\hline U1329E-8Y-1, 35 & 104.35 & 64 & & & 100 & & & & 6.93 & -6.39 & & \\
\hline U1329C-17H-1, 0 & 135.60 & 68 & & 90 & 10 & & 4.6 & -11.67 & & & & \\
\hline U1 329C-18X-2, 65 & 142.35 & 76 & & 45 & 55 & & 6.58 & 20.04 & & & & \\
\hline U1329C- $18 X-5,18$ & 146.38 & 89 & & & 100 & & & & 6.03 & 24.15 & & \\
\hline U1329C-18X-5, 27 & 146.47 & 81 & & & 100 & & & & 6.14 & 21.18 & & \\
\hline U1329C-19X-1, 64 & 150.54 & 33 & & 7 & & 93 & & & & & 5.66 & 37.55 \\
\hline U1329C-20X-1, 70 & 160.30 & 78 & & 100 & & & 3.88 & -19.58 & & & & \\
\hline U1329C-20X-1, 89 & 160.49 & 80 & & 100 & & & 3.62 & 8.48 & & & & \\
\hline U1329C-20X-1, 125 & 160.85 & 82 & & 100 & & & 3.99 & -21.28 & & & & \\
\hline U1329C-20X-3, 34 & 162.94 & 81 & & 100 & & & 4.05 & -21.26 & & & & \\
\hline U1329C-20X-5, 34 & 165.44 & 70 & & 100 & & & 3.68 & -30.69 & & & & \\
\hline U1329C-20X-CC, 19 & 166.00 & 83 & & & 100 & & & & 4.28 & 33.46 & & \\
\hline U1329C-21X-2, 118 & 171.98 & 44 & & 36 & 8 & 56 & & & & & 4.55 & 26.76 \\
\hline U1329C-21X-3, 61 & 172.91 & 53 & & 100 & & & 3.37 & -10.88 & & & & \\
\hline U1329C-21X-3, 129 & 173.59 & 16 & & 38 & & 62 & & & & & 4.71 & 29.34 \\
\hline U1329C-21X-3, 129 CARB & 173.59 & 64 & & 18 & & 82 & & & & & 4.99 & 30.81 \\
\hline U1329C-21X-6, 0 & 176.30 & 82 & & 1 & 99 & & & & 4.3 & 33.46 & & \\
\hline U1329C-22X-CC, 72 & 187.75 & 60 & & 100 & & & -8.68 & 3.5 & & & & \\
\hline
\end{tabular}

Notes: $\mathrm{VPDB}=$ Vienna Peedee belemnite. $\mathrm{CARB}=$ small veinlet of carbonate. ${ }^{*}=$ rhodochrosite + siderite. All other values in Other carbonate column are for siderite 